\title{
EFFECT OF FERMENTATION ON APPARENT TOTAL AND NUTRIENT DIGESTIBILITY OF LINSEED, LINUM USITATISSIMUM, MEAL IN ROHU, LABEO ROHITA, FINGERLINGS
}

\author{
Nibedita MUKHOPADHYAY ${ }^{1 *}$, Arun K. RAY ${ }^{2}$ \\ ${ }^{1}$ Department of Biotechnology, CSJM University, Kanpur, Kanpur, India \\ ${ }^{2}$ Department of Zoology, Visva-Bharati University, Santiniketan, West Bengal, India
}

\begin{abstract}
Mukhopadhyay N., Ray A.K. 2005. Effect of fermentation on apparent total and nutrient digestibility of linseed, Linum usitatissimum, meal in rohu, Labeo rohita, fingerlings. Acta Ichthyol. Piscat. 35 (2): 73-78.
\end{abstract}

Background. Linseed and its by-products constitute a major source of dietary protein, but due to aminoacid imbalance and presence of anti-nutritional factors their use in fish feed is limited. Therefore, fermentation of linseed by lactic acid bacteria and/or fermented diets increases the level of linseed inclusion into the diet of rohu fingerlings by up to 40 percentage points.

Materials and Methods. Six experimental diets (RL20, RL30, RL40, FL20, FL30, and FL40) for rohu fingerlings (Labeo rohita) were formulated using raw and fermented linseed meals. Finely powdered $(400 \mu \mathrm{m})$ diet ingredients were incorporated at 3 different levels $(20,30$, and $40 \%)$ into each diet, replacing equal proportions of all the ingredients from the reference diet. Two types of de-oiled linseed, Linum usitatissimum, meals were used as test ingredients: raw (RL) and fermented (FL). Prior to incorporation, a portion of the linseed meal was fermented by inoculating it with lactic acid bacteria, Lactobacillus acidophilus. The reference diet was prepared with fish meal as the chief protein source.

Results. Fermentation of the oilseed meal resulted in reduction of tannin content from $2.45 \%$ to $1.32 \%$. The total digestibility of the reference and test diets was significantly higher $(P<0.01)$ at all levels of fermented linseed addition. In particular, it was observed that the fermented samples showed comparatively better digestibility than the raw samples.

Conclusions. Fermentation of oilseed meals which leads to the reduction of anti-nutritional factors may be applied as an efficient tool in formulation of feeds for rohu fingerlings.

Key words: anti-nutritional factors, fish feed, diets, fermentation, linseed meal, digestibility, fingerlings, rohu, Labeo rohita, fish

\section{INTRODUCTION}

Plant oilseeds and their by-products usually constitute a major source of dietary protein in feeds of warm water omnivorous/herbivorous fish species (Lim and Dominy 1991). Some of the factors which limit application of these ingredients in fish feeds at high levels include low protein content, amino-acid imbalance, and the presence of antinutritional factors (Wee 1991). In India, the digestibility of locally available feed ingredients has been a subject of a few studies, conducted on carp (Jayaram and Shetty 1980, Ray and Das 1994, Mukhopadhyay and Ray 1997).

Linseed meal is often used as a dietary ingredient in fish feed. Hasan et al. (1989) used linseed meal as a feed ingredient in the diet of walking catfish, Clarias batrachus, fry. Hasan et al. (1991) used it successfully in the diet of Labeo rohita. Hossain and Jauncey (1989) studied the protein, energy content, and amino acid digestibility of linseed meal. The low apparent protein digestibility of linseed might be due to the presence of mucilage in it. In addition, Hossain and Jauncey (1989) investigated the nutritive value of linseed meal of Bangladeshi origin and tested it in a diet of common carp, Cyprinus carpio. Earlier, studies on the digestibility of an ingredient usually involved the reference diet to the ingredient ratio of $7: 3$ ratio (Cho et al. 1974). De Silva et al. (1990), however, have shown that a desirable proportion of the ingredient relative to the reference diet should vary from $80 \%-85 \%$ to $20 \%-15 \%$.

In this study, an attempt was made to evaluate the suitability of incorporating raw and fermented linseed meal

\footnotetext{
* Correspondence: Dr Nibedita Mukhopadhyay, Department of Biotechnology, CSJM University, Kanpur, Kanpur, India, PIN 208024; c/o Dr. Animesh Das, Department of Civil Engineering, Indian Institute of Technology Kanpur, Kanpur- 208 016, India, e-mail: nibeditta@hotmail.com
} 
into the diets of rohu (Labeo rohita) fingerlings by determining the digestibility coefficient of the ingredient. Fermentation involves synthesis of a high quality protein in the form of microbial bodies. Fermentative microbes are able to synthesise all the amino acids and render them easily available; in some cases, fermentative microbes utilise urea to synthesise protein. Digestibility coefficients of the diets were determined in diets incorporating both types of linseed meal (raw and fermented) at different inclusion levels $(20 \%-40 \%)$ to find the best level of the ingredient.

\section{MATERIALS AND METHODS}

Experimental diets. Two types of de-oiled linseed (Linum usitatissimum) meal were used as test ingredients: raw and fermented. Prior to incorporation, a portion of the linseed meal was fermented by inoculating it with lactic acid bacteria, Lactobacillus acidophilus $\left(10^{6}\right.$ cells $\left.\cdot \mathrm{g}^{-1}\right)$ at a 5\% level and keeping the inoculated meal at room temperature $\left(28-30^{\circ} \mathrm{C}\right)$ for $48 \mathrm{~h}$. The fermented samples were then sun-dried, pulverised in a grinder, and sieved to obtain particles smaller than $400 \mu \mathrm{m}$. The reference diet was prepared according to Ray and Das (1994), with fish meal as the main protein source. Six experimental diets (RL20, RL30, RL40, FL20, FL30, and FL40) were formulated using raw and fermented linseed meals. The finely powdered $(400 \mu \mathrm{m})$ test ingredients were incorporated in each diet at 3 different levels $(20,30$, and $40 \%)$ by replacing equal proportions of all the ingredients from the reference diet. To each of the formulated diets, $1 \%$ chromic oxide was added as an external marker. All the diets were in pelleted form, with carboxymethyl cellulose as a binder.

Experimental design. The experiment was conducted in a static indoor rearing system containing 90-L glass aquaria with continuous aeration. Fingerlings of rohu, Labeo rohita (Hamilton, 1822), were obtained from a local fish seed dealer and acclimated to the laboratory conditions for 15 days; they were fed a 1:1 mixture of rice bran and mustard oilcake. The fingerlings (mean weight $4.50 \pm 0.11 \mathrm{~g}$ ) were randomly assigned to the aquaria at the density of 10 fish per aquarium; each treatment was run at two replicates. Each experimental aquarium was fed with de-chlorinated water from a deep tube well. The experimental fish were fed the formulated diets twice a day (at 0900 and $1500 \mathrm{~h}$ ) at a fixed feeding rate of $5 \%$ body wet weight per day for the whole 60-day long period of experiment. The quantity of feed offered was readjusted every 10th day after the fish were weighed. The uneaten feed was collected by siphoning $1 \mathrm{~h}$ after each feeding. The faecal samples were collected following the method outlined by Spyridakis et al. (1989). The faeces, naturally released by the fish, were easily detectable and removed from the water with a glass canula. The collection was performed continuously, 3 to $4 \mathrm{~h}$ after feeding. The faecal material collected was rinsed in distilled water and kept at $-80^{\circ} \mathrm{C}$ before freeze drying for analysis. The faecal samples were analysed in triplicate. The pooled faecal samples from each treatment were analysed separately. At the termination of the experiment, all the fishes were weighed individually and used for subsequent analysis.

The water in each tank was changed every day throughout the period of the experiment to maintain appropriate water quality. The water temperature, $\mathrm{pH}$, dissolved oxygen content, and alkalinity ranged within $26-30^{\circ} \mathrm{C}, 6.3-7.3$, $4.9-7.7 \mathrm{mg} \cdot \mathrm{L}^{-1}$, and, $189-190 \mathrm{mg} \cdot \mathrm{L}^{-1}$, respectively.

Chemical and statistical analyses. Feed ingredients, experimental diets, faecal samples, and fish carcasses were analysed for proximate composition following the AOAC (Anonymous 1990) procedures. The chromic oxide contents in the diets and faeces were estimated spectrophotometrically following the method of Bolin et al. (1952). The tannin content in the de-oiled seed meals was determined using the Folin-Denis reagent (Schanderi 1970), whereas the phytic acid content was determined following the method outlined by Wheeler and Ferrel (1971). Apparent total and nutrient digestibility values were calculated by employing the following formulae (De Silva and Anderson 1995):

(a) Apparent total digestibility (\%) of the reference (RD) and test (TD) diets:

$100-100$ (\% marker in diet/\% marker in faeces)

(b) Apparent nutrient digestibility of RD and TD:

$100-100(\%$ marker in diet $/ \%$ marker in faeces $\times \%$ nutrient in faeces $/ \%$ nutrient in diet)

where: nutrient refers to any nutrient, e.g. protein or fat.

(c) Apparent dry matter digestibility of the ingredient:

$100 / \%$ test ingredients (apparent TD total digestibility $\% \mathrm{RD} / 100 \times$ apparent $\mathrm{RD}$ total digestibility)

(d) Apparent nutrient digestibility of the ingredient: $100 / \%$ test ingredient (TD nutrient digestibility $\% \mathrm{RD} / 100 \times \mathrm{RD}$ nutrient digestibility).

Statistical treatment of the data involved analysis of variance (ANOVA) followed by Scheff's F-test for multiple comparisons (Das and Das 1993). The differences were considered significant at the probability level of 0.01 .

\section{RESULTS}

The proximate composition of linseed meal and other ingredients are presented in Table 1 . The ingredient composition (\% dry weight) and proximate composition of the experimental diets are presented in Table 2.

The anti-nutritional factor (phytic acid from linseed meal) could be reduced below detection limit by fermentation with lactic acid bacteria, Lactobacillus acidophilus. Fermentation of the oilseed meal resulted in reduction of the tannin content from 2.45 to 1.32 percentage points.

The data regarding apparent dry matter (or total) and nutrient digestibility of the reference and test diets are presented in Table 3 . The total digestibility of the reference and test diets was significantly higher $(P<0.01)$ at all levels of incorporation. The apparent protein digestibility was, however, significantly $(P<0.01)$ higher at all the levels of incorporation in the fermented linseed meal treatments, while diets containing raw linseed meal showed a poor protein digestibility. The apparent digestibility (AD) 
Proximate composition of feed ingredients [\% dry matter basis]

\begin{tabular}{|c|c|c|c|c|c|}
\hline Component & Fish meal & $\begin{array}{l}\text { Mustard } \\
\text { oilcake }\end{array}$ & Rice bran & $\begin{array}{l}\text { Raw linseed } \\
\text { meal }(\mathrm{RL})\end{array}$ & $\begin{array}{l}\text { Fermented } \\
\text { linseed meal } \\
(\mathrm{FL})\end{array}$ \\
\hline Moisture & 2.96 & 14.00 & 4.45 & 5.10 & 5.15 \\
\hline Crude protein & 58.50 & 35.93 & 13.00 & 37.10 & 38.26 \\
\hline Lipids & 8.91 & 7.00 & 5.14 & 13.00 & 14.32 \\
\hline Ash & 11.50 & 8.37 & 21.41 & 9.50 & 9.50 \\
\hline Crude fibre & 3.93 & 5.53 & 25.50 & 5.50 & 5.50 \\
\hline $\begin{array}{l}\text { Nitrogen-free } \\
\text { extract (NFE) }\end{array}$ & 14.20 & 29.17 & 30.50 & 29.80 & 27.27 \\
\hline $\begin{array}{l}\text { Gross energy } \\
{\left[\mathrm{kcal} \cdot \mathrm{g}^{-1}\right]}\end{array}$ & 4.19 & 4.11 & 3.52 & 4.77 & 4.77 \\
\hline Tannin & - & - & - & 2.45 & 1.32 \\
\hline Phytic acid & - & - & - & 0.08 & - \\
\hline
\end{tabular}

Table 1

Table 2

Ingredient composition [\% dry weight] and proximate composition of the experimental diets [on dry matter basis]

\begin{tabular}{|c|c|c|c|c|c|c|c|c|}
\hline & \multirow{2}{*}{ Diet } & \multirow{2}{*}{$\mathrm{RD}^{3}$} & \multicolumn{3}{|c|}{ Raw linseed meal } & \multicolumn{3}{|c|}{ Fermented linseed meal } \\
\hline & & & RL20 & RL30 & RL40 & FL20 & FL30 & FL40 \\
\hline \multirow{7}{*}{ 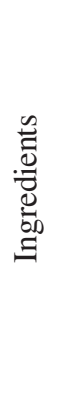 } & Fish meal & 40.0 & 32.0 & 28.0 & 24.0 & 32.0 & 28.0 & 24.0 \\
\hline & Mustard oilcake & 23.0 & 18.0 & 34.0 & 14.0 & 18.0 & 34.0 & 14.0 \\
\hline & Rice bran & 35.0 & 28.0 & 6.0 & 20.0 & 28.0 & 6.0 & 20.0 \\
\hline & Linseed (raw) & - & 20.0 & 30.0 & 40.0 & - & - & - \\
\hline & Linseed (fermented) & - & - & - & - & 20.0 & 30.0 & 40.0 \\
\hline & Premix $^{1}$ & 1.0 & 1.0 & 1.0 & 1.0 & 1.0 & 1.0 & 1.0 \\
\hline & Chromic oxide & 1.0 & 1.0 & 1.0 & 1.0 & 1.0 & 1.0 & 1.0 \\
\hline \multirow{10}{*}{ 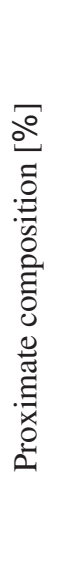 } & Dry matter & 90.01 & 90.17 & 92.01 & 91.54 & 93.65 & 90.37 & 90.13 \\
\hline & Crude protein & 35.96 & 35.24 & 36.31 & 34.99 & 35.92 & 36.50 & 35.87 \\
\hline & Lipid & 6.72 & 8.35 & 9.13 & 9.40 & 9.43 & 8.77 & 10.17 \\
\hline & Ash & 15.40 & 14.63 & 12.39 & 12.20 & 12.93 & 12.57 & 13.32 \\
\hline & Crude fibre & 11.77 & 10.48 & 6.20 & 12.47 & 9.03 & 5.93 & 4.07 \\
\hline & $\mathrm{NFE}^{2}$ & 20.16 & 21.47 & 27.98 & 21.54 & 24.23 & 26.60 & 21.70 \\
\hline & Gross energy & & & & & & & \\
\hline & {$\left[\mathrm{kcal} \cdot \mathrm{g}^{-1}\right]$} & 4.19 & 4.29 & 4.35 & 4.26 & 4.37 & 4.42 & 4.42 \\
\hline & Tannin [\%] & 一 & 0.52 & 0.82 & 1.12 & 0.30 & 0.51 & 0.68 \\
\hline & Phytic acid [\%] & - & 0.02 & 0.02 & 0.03 & - & - & - \\
\hline
\end{tabular}

${ }^{1}$ Vitamin and mineral mixture (Vitaminetes Forte, Roche Products Ltd., 24/28 Pt. M.M. Malviya Road Bombay 400034, India); ${ }^{2}$ Nitrogen-free extract; ${ }^{3}$ Reference diet 
of protein was significantly $(P<0.01)$ higher than that of the reference diet in the fermented linseed meal-containing diets up to $40 \%$ inclusion levels. The apparent fat digestibility was significantly $(P<0.01)$ higher in the treated (fermented) linseed meal-containing diets up to $40 \%$ inclusion level, compared with the reference diet. The dry matter (or total) and nutrient digestibility of the test ingredient (both raw and fermented) at different levels of inclusion is presented in Table 4.

\section{DISCUSSION}

The replacement of fishmeal by alternate sources of protein has met with varied degree of success, depending on the nature and composition of ingredients, inclusion level, and method of processing (Tacon and Jackson 1985, De Silva and Gunasekara 1991, Ray and Das 1992, Mukhopadhyay and Ray 1996, 1997, 1999). This study shows clearly that the nature, source, and composition of ingredients and their inclusion level affects the degree of digestibility.

The AD of protein was highest in the fishmeal-based reference diet, compared to the diets containing raw linseed meals at different inclusion levels. The data are comparable to those reported by Hossain and Jauncey (1989) from Cyprinus carpio fed diets containing different proportions of linseed meals. In contrast, Hasan et al. (1991) reported lower $\mathrm{AD}$ of protein for the control diet in comparison with $40 \%$ linseed protein diets in Labeo rohita fry. According to National Research Council (NRC) (Anonymous 1977), carp can digest up to $95 \%$ of fishmeal protein. However, the values may decrease to $80 \%-85 \%$, depending on the origin and processing of fishmeal (Ogino and Chen 1973). The AD of protein for the treated linseed meals was found to increase with increasing inclusion level. The AD of protein for the treated linseed mealcontaining diets at $30 \%$ inclusion level were comparable to that for the reference diet. The value was however, higher, in the $40 \%$ treated linseed meal diet than in the reference diet. Hasan et al. (1991) reported increased apparent digestibility of protein at higher levels of raw linseed meal incorporation in the diets of Labeo rohita fry.

The apparent lipid digestibility (ALD) of the reference diet $(89.30 \%)$ was similar to that recorded in Cyprinus carpio (89.31\%; Hossain and Jauncey 1989). The ALD values obtained in the present study with the raw linseed meal-containing diets are similar to those of linseed mealenriched $(84.52 \%$ to $89.81 \%$ ) diets for Cyprinus carpio (cf. Hossain and Jauncey 1989). The decrease in ALD with increasing levels of inclusion of raw linseed meals was in agreement with the observation of Hossain and Jauncey (1989). However, in the case of treated linseed meal-containing diets, the ALD value increased with the increasing inclusion level. The values were comparable to the reference diet at $40 \%$ level of inclusion of fermented linseed meals. The present results, however, indicate a decrease in protein and fat digestibility with decreasing crude fibre levels in the diets, regardless of treatment.

It is generally recognised that digestibility data are useful only when ingredients do not contain gossypol-like substances, tannin, complex polysaccharides, antitrypsin, and other interfering substances which may affect the digestibility of various nutrients in the diet and give erro-

Apparent dry matter (or total) and nutrient digestibility [\%] of the reference and test diets $(\bar{x} \pm s)$

\begin{tabular}{|c|c|c|c|c|c|c|c|}
\hline Nutrient & $\mathrm{RD}$ & RL20 & RL30 & RL40 & FL20 & FL30 & FL40 \\
\hline $\begin{array}{l}\text { Dry } \\
\text { matter } \\
\text { (or total) }\end{array}$ & $69.90^{\mathrm{a}} \pm 0.11$ & $72.60^{b} \pm 0.11$ & $71.70^{b} \pm 0.12$ & $70.60^{b} \pm 0.09$ & $67.10^{\mathrm{a}} \pm 0.08$ & $72.60^{b} \pm 0.11$ & $71.22^{\mathrm{b}} \pm 0.09$ \\
\hline Protein & $88.90^{c} \pm 0.11$ & $86.30^{\mathrm{a}} \pm 0.12$ & $87.60^{\mathrm{b}} \pm 0.09$ & $84.70^{\mathrm{a}} \pm 0.12$ & $87.90^{\mathrm{b}} \pm 0.09$ & $88.60^{c} \pm 0.13$ & $89.66^{\mathrm{d}} \pm 0.09$ \\
\hline Fat & $89.30^{\mathrm{d}} \pm 0.11$ & $83.70^{\mathrm{a}} \pm 0.09$ & $88.20^{c} \pm 0.11$ & $84.20^{\mathrm{a}} \pm 0.09$ & $85.40^{\mathrm{b}} \pm 0.13$ & $88.80^{c} \pm 0.15$ & $89.54^{\mathrm{d}} \pm 0.07$ \\
\hline
\end{tabular}

Values having the same superscript letter in the same row are not significantly different $(P<0.01) ; n=2$ (all values are means of two replicates)

Apparent dry matter (or total) and nutrient digestibility [\%] of raw and fermented test ingredients

Table 4

\begin{tabular}{lcccccc}
\hline \multicolumn{1}{c}{ Nutrient } & RL20 & RL30 & RL40 & FL20 & FL30 & FL40 \\
\hline $\begin{array}{l}\text { Dry matter } \\
\text { (or total) }\end{array}$ & $83.15^{\mathrm{f}} \pm 0.11$ & $75.95^{\mathrm{d}} \pm 0.10$ & $71.65^{\mathrm{b}} \pm 0.14$ & $55.40^{\mathrm{a}} \pm 0.11$ & $78.75^{\mathrm{e}} \pm 0.13$ & $73.10^{\mathrm{c}} \pm 0.09$ \\
Protein & $75.55^{\mathrm{a}} \pm 0.12$ & $84.40^{\mathrm{c}} \pm 0.10$ & $78.33^{\mathrm{b}} \pm 0.13$ & $84.00^{\mathrm{c}} \pm 0.09$ & $87.73^{\mathrm{d}} \pm 0.11$ & $90.68^{\mathrm{e}} \pm 0.08$ \\
Fat & $61.17^{\mathrm{a}} \pm 0.17$ & $85.34^{\mathrm{d}} \pm 0.12$ & $76.37^{\mathrm{c}} \pm 0.11$ & $69.52^{\mathrm{b}} \pm 0.09$ & $87.44^{\mathrm{e}} \pm 0.12$ & $89.79^{\mathrm{f}} \pm 0.15$ \\
\hline
\end{tabular}

Values having the same superscript letter in the same row are not significantly different $(P<0.01) ; n=2$ (all values are means of two replicates) 
neous results (Lall 1991). The fermented linseed meal diets contained $0.30 \%, 0.51 \%$, and $0.68 \%$ tannin at $20 \%$, $30 \%$, and $40 \%$ inclusion levels, respectively. As stated earlier, fermentation of linseed meal results in complete elimination of phytic acid. A better digestibility of protein and lipid from the fermented linseed meal-containing diets may be attributed to the absence of phytic acid in those diets. Teutino and Knorr (1985) also reported increased digestibility of protein and fat from the fermented samples of misco (rice + soya), wheat soybean tempeh, and natto (soybean) in humans. There has hitherto been no report, however, on the digestibility of nutrients from fermented oilseed meals in fish.

\section{CONCLUSIONS}

Anti-nutritional factors such as tannin and phytic acid as well as amino acid imbalance limit high levels of inclusion of linseed meal into fish feeds. By eliminating/reducing the amount of tannin and phytic acid via appropriate processing involving fermentation, a better digestibility of protein and fat is attained.

\section{ACKNOWLEDGEMENTS}

The authors are grateful to the Indian Council for Agricultural Research (ICAR), New Delhi for providing financial support during the work.

\section{REFERENCES}

Anonymous 1977. Nutrient requirements of warmwater fishes. NRC (National Research Council). National Academy of Sciences. Subcommittee on Fish Nutrition.

Anonymous 1990. Official methods of analysis of AOAC International. 15th edn. Association of Analytical Chemists Inc., Arlington, VA.

Bolin D.W., King R.P., Klosterman F.W. 1952. A simplified method for the determination of chromic oxide $\left(\mathrm{Cr}_{2} \mathrm{O}_{3}\right)$ when used as an index substance. Science 116: 634-635.

Cho C.Y., Bayley H.S., Slinger S.J. 1974. Partial replacement of herring meal with soybean meal and other changes in a diet for rainbow trout (Salmo gairdneri). Journal of the Fisheries Research Board of Canada 31: 1523-1528.

Das D., Das A. 1993. Statistics in biology and psychology. Academic Publishers, Calcutta.

De Silva S.S., Anderson T.A. 1995. Fish nutrition in aquaculture. Chapman and Hall, London.

De Silva S.S., Gunasekara R.M. 1991. An evaluation of the growth of Indian and Chinese major carps in relation to the dietary protein content. Aquaculture 92: 237-241.

De Silva S.S., Shim K.F., Khim Ong A. 1990. An evaluation of the method used in digestibility estimations of a dietary ingredient and comparisons on external and internal markers and time of faeces collection in digestibility studies in the fish Oreochromis aureus (Steindachner). Reproduction, Nutrition, Development 30: 215-226.

Hasan M.R., Alam M.G.M., Islam M.A. 1989. Evaluation of some indigenous ingredients as dietary protein sources for the catfish (Clarias batrachus Linnaeus) fry. pp. 125-137.
In: Huisman E.A., Zonniveld N., Beuwmangs A.H.M. (eds) Aquacultural research in Asia: management techniques and nutrition. Center for Agricultural Publishing and Documentations. Pudoc Scientific Publishers, Wageningen.

Hasan M.R., Azad A.K., Omar Farooque A.M.O., Akand A.M., Das P.M. 1991. Evaluation of some oilseed cakes as dietary protein sources for the fry of Indian major carp, Labeo rohita (Hamilton). pp. 107-117. In: De Silva S.S. (ed.) Fish nutrition research in Asia. Proceedings of the fourth Asian fish nutrition workshop. Asian Fisheries Society, Special Publication No. 5, Manila.

Hossain M. A, Jauncey K. 1989. Nutritional evaluation of some Bangladeshi oilseeds meals as partial substitutes for fish meal in the diet of common carp, Cyprinus carpio L. Aquaculture and Fisheries Management 20: 225-268.

Jayaram M.G., Shetty H.P.C. 1980. Digestibility of two pelleted diets by Cyprinus carpio and Labeo rohita. Mysore Journal of Agricultural Sciences 14: 578-584.

Lall S.P. 1991. Concepts in the formulation and preparation of a complete fish diet. pp. 1-12. In: De Silva S.S. (ed.) Fish nutrition research in Asia. Proceedings of the fourth Asian fish nutrition workshop. Asian Fisheries Society, Special Publication No. 5, Manila.

Lim C., Dominy W. 1991. Utilization of plant proteins by warm water fish. pp. 163-172. In: Akiyama D.M., Tan R.K.H. (eds.) Proceedings of the aquaculture feed processing and nutrition workshop. Thailand and Indonesia, American Soybean Association, Singapore, September 19-25.

Mukhopadhyay N., Ray A.K. 1996. The potential of deoiled sal (Shorea robusta) seed meal as feedstuff in pelleted feed for Indian major carp, rohu, Labeo rohita (Hamilton), fingerlings. Aquaculture Nutrition 2: 221-227.

Mukhopadhyay N., Ray A.K. 1997. The apparent total and nutrient digestibility of sal seed (Shorea robusta) meal in rohu, Labeo rohita (Hamilton), fingerlings. Aquaculture Research 28: 683-689.

Mukhopadhyay N., Ray A.K. 1999. Utilization of copra meal in the formulation of compound dies for rohu, Labeo rohita, fingerlings. Journal of Applied Ichthyology 15: 127-131.

Ogino C., Chen M.-S. 1973. Protein nutrition in fish. V. Relation between biological value of dietary protein and their utilization in carp. Bulletin of the Japanese Society of Scientific Fisheries (Nippon Suisan Gakkaishi) 39: 955-959.

Ray A.K., Das I. 1992. Utilization of diets containing composted aquatic weed (Salvinia cuculata) by the Indian major carp, rohu (Labeo rohita Ham.), fingerlings. Bioresource Technology 40: 67-72.

Ray A.K., Das I. 1994. Apparent digestibility of some aquatic macrophytes in rohu, Labeo rohita (Ham.) fingerlings. Journal of Aquaculture in the Tropics 9: 335-342.

Schanderi S.H. 1970. Methods in food analysis. Academic Press, New York.

Spyridakis P., Metailler R., Gabaudan J., Riaza A. 1989. Studies on nutrient digestibility in European sea bass (Dicentrarchus labrax). I. Methodological aspects concerning faeces collection. Aquaculture 77: 61-70. 
Tacon A.G.J., Jackson A.J. 1985. Utilization of conventional and unconventional protein sources in practical fish feeds. pp. 119-145. In: Cowey C.B., Mackie A.M., Bell J.G. (eds.) Nutrition and feeding in fish. Academic Press, London.

Teutino R.A., Knorr D. 1985. Impact of biotechnology on nutritional quality of food plants. Food Technology 39 (10): 127-134.

Wee K.L. 1991. Use of non-conventional feedstuffs of plant origin as fish feeds-is it practical and economically feasible? pp. 13-32. In: De Silva S.S. (ed.) Fish nutrition research in
Asia. Proceedings of the fourth Asian fish nutrition workshop. Asian Fisheries Society, Special Publication No. 5, Manila.

Wheeler E.L., Ferrel R.E. 1971. A method for phytic acid determination in wheat and wheat fractions. Cereal Chemistry 48: 312-320.

Received: 24 January 2005 Accepted: 1 October 2005 